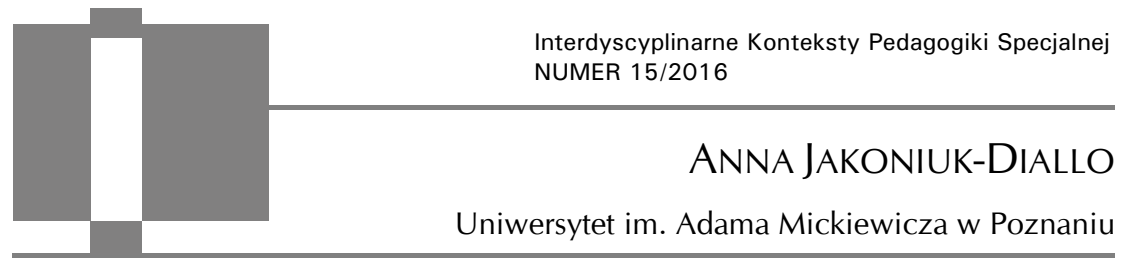

\title{
Ocena dojrzałości szkolnej dzieci z wadą słuchu. Kontrowersje i wyzwania związane z diagnozą psychologiczno-pedagogiczną
}

\begin{abstract}
Anna Jakoniuk-Diallo, Ocena dojrzałości szkolnej dzieci z wada stuchu. Kontrowersje $i$ wyzwania zwiazane $z$ diagnoza psychologiczno-pedagogiczna [Evaluation of readiness for school education of children with hearing impairment. Controversies and challenges related to psychological-pedagogical diagnosis]. Interdyscyplinarne Konteksty Pedagogiki Specjalnej, nr 15, Poznań 2016. Pp. 79-91. Adam Mickiewicz University Press. ISSN 2300-391X

The start of school education is an important and difficult phase in every child's life. However with each one of them, we have to deal with the individual pace and specificity of development in each sphere, and even so it is difficult to recognize every child as equally mature as a pupil. Both the evaluation of child progress in the education process and the readiness for school education are made through the prism of linguistic proficiency.

In the case of child's hearing loss, especially when it is congenital or acquired at a very early stage, the development of speech and language is delayed. The determinant of this situation is the lack of access to the audible voice of the guardians. In a slightly different situation there are children with hearing impairment, having deaf parents. These people, from their earliest years, develop their sign language skills, which are primary to them. An increasing number of hearing impaired children go to integration classes in public schools. Does this mean that the psychological and pedagogical diagnosis procedure of the aforementioned group of children, including the study of their school maturity, can be considered appropriate?
\end{abstract}

KEY WORDS: child with hearing impairment, pedagogical diagnosis, school maturity 


\section{Wprowadzenie}

Okres rozpoczęcia edukacji szkolnej to ważny i trudny, bo związany z realizacją zadań rozwojowych, etap w życiu każdego dziecka. Przygotowanie do dorosłości obejmuje uczestnictwo w procesie nauczania - uczenia się, który umożliwia nabywanie nowych kompetencji, doświadczanie ról i relacji. Dotychczasowa spontaniczna dziecięca aktywność zabawowa musi ustąpić miejsca realizacji szkolnych obowiązków, przy tym w dużej mierze mają one charakter działań przymusowych (narzuconych). Do innych zadań, z którymi w okresie szkolnym przychodzi mierzyć się uczniowi, należą przestrzeganie norm społecznych oraz zdobywanie wiedzy o świecie i o sobie. Ich realizacja możliwa jest dzięki zmianom, które zachodzą w sferze rozwoju poznawczego i społeczno-emocjonalnego dziecka. W przypadku różnych osób mamy jednak do czynienia z indywidualnym tempem oraz specyfiką rozwoju w poszczególnych obszarach i chociażby z tego względu trudno jest uznać każde dziecko za jednakowo dojrzałe do roli ucznia. Różnice, o których mowa, warunkowane są przede wszystkim indywidualnym tempem rozwoju układu nerwowego ${ }^{1}$. Tymczasem za główny wskaźnik poziomu rozwoju intelektualnego dziecka uważa się jego kompetencje komunikacyjną i językową. To przez pryzmat sprawności językowej dokonywana jest zarówno ewaluacja dziecięcych postępów w procesie kształcenia, jak i gotowości do podjęcia nauki szkolnej. W przypadku wystąpienia u dziecka wady słuchu, szczególnie wówczas, gdy ma ona charakter odbiorczy, wrodzony lub nabyty w bardzo wczesnym okresie, rozwój mowy dźwiękowej i języka fonicznego jest opóźniony. Determinantą tej sytuacji jest brak dostępu do mowy dźwiękowej słyszących opiekunów. W nieco innej sytuacji są dzieci z wadą słuchu posiadające rodziców Głuchych².

${ }^{1}$ A. Brzezińska, J. Matejczuk, A. Nowotnik, Wspomaganie rozwoju dzieci 5-7 letnich a ich gotowość do radzenia sobie z wyzwaniami szkoły, „Edukacja” 2012, 1(117), s. 7-22.

2 "Gtuchy" pisane duża litera odnosi się do członkostwa w Kulturze Głuchych, jej norm, wartości, przekonań, które różnia się od kultury styszących. Duża litera G stuży 
Te od najmłodszych lat rozwijają umiejętność posługiwania się językiem migowym, który jest dla nich prymarny. Dostęp do tego języka nie tylko umożliwia dzieciom rozwój kompetencji komunikacyjnej, ale jest decydujący dla ich rozwoju społeczno-emocjonalnego. W praktyce to właśnie dzieci posługujące się funkcjonalnie migami, jeżeli tylko stworzy im się warunki do opanowania podstaw języka fonicznego, osiągają wyższy poziom biegłości w zakresie obu języków niż dzieci rodziców słyszących rehabilitowane metodą audytywno-werbalną. W tej grupie sporej liczbie dzieci do czasu rozpoczęcia nauki szkolnej udaje się opanować zaledwie podstawy polskiego języka fonicznego. Następstwem tej sytuacji jeszcze do niedawna było wnioskowanie słyszących rodziców o wydanie dla ich niesłyszącego dziecka orzeczenia o potrzebie kształcenia specjalnego. W ostatnich latach sytuacja ta uległa zmianie. Coraz większa liczba dzieci z wadą słuchu trafia do klas integracyjnych w szkołach ogólnodostępnych i kształcona jest w warunkach inkluzji. Czy to oznacza, że procedurę diagnozy psychologiczno-pedagogicznej wyżej wymienionej grupy dzieci, w tym badanie ich dojrzałości szkolnej, możemy uznać za właściwą? Niestety nie. Niedostatek narzędzi psychologicznych, wyposażonych w normy dla dzieci niesłyszących i słabosłyszących oraz wciąż niewielka liczba pracowników poradni, w tym pedagogów, posługujących się językiem migowym stanowią bariery właściwej oceny rozwoju wymienionej grupy osób.

zdeklarowaniu, że stan gtuchoty jest raczej przynależnościa kulturowa aniżeli tylko stanem zdrowia. Na przykład zdania: (1) "Jestem głuchy" oznacza postrzeganie siebie jako osoby, która utraciła stuch; (2) "Jestem Głuchy" oznacza członkostwo w Kulturze Gtuchych. Termin "gtuchy" pisane mała litera odnosi się do osoby, która charakterryzuje się głęboka (powyżej $90 \mathrm{~dB}$ ) utrata stuchu. Jej możliwości percepcyjne droga stuchowa sa tak ograniczone, że nie jest w stanie w sposób naturalny opanować języka mówionego czy tė̇ naturalnie jej używać w codziennej komunikacji. Cytat pochodzi z: Nauczmy się rozumieć nawzajem, Poradnik dla słyszących o niedosłyszących i głuchych Wydawca: Polski Związek Głuchych Zarząd Główny www.pzg.org.pl [dostęp: 10.11.2016]. 


\section{Procedura orzekania o dojrzałości szkolnej dziecka $\mathrm{z}$ wadą słuchu}

Dokonywanie oceny rozwoju poznawczego i społeczno-emocjonalnego dzieci z wadą słuchu jest dla większości diagnostów zadaniem trudnym. Przesądza o tym kilka czynników. Przede wszystkim fakt braku narzędzi. Jednym z nielicznych jest Międzynarodowa Skala Leitera ${ }^{3}$. Kolejny czynnik to niespecyficzny rozwój dzieci, u których przyczyną wady słuchu stało się uszkodzenie ośrodkowego układu nerwowego. U dzieci z odbiorczymi wadami słuchu częściej niż u słyszących rówieśników diagnozuje się ADHD, zaburzenia emocjonalne, trudności adaptacyjne ${ }^{4}$. Poza wymienionymi czynnikami specyfikę funkcjonowania każdego dziecka $\mathrm{z}$ wadą słuchu warunkują te inne elementy - związane $\mathrm{z}$ indywidualnym rozwojem i jego warunkami. Należą do nich: rodzaj oraz stopień ubytku słuchu, czas objęcia dziecka działaniami rehabilitacyjnymi, specyfika przebiegu procesów poznawczych z uwzględnieniem dominujących procesów percepcji czy wreszcie stopień stymulacji słuchowej ze strony najbliższego otoczenia. Czynniki te wpływają z pewnością na stopień opanowania przez dziecko z wadą słuchu języka polskiego. Skalę problemu ilustrują m.in. badania Magdaleny Dunaj5, z których wynika, że dzieci te w następstwie doświadczanych trudności edukacyjnych nierzadko trafiają do szkół specjalnych. Ponadto połowa osób z uszkodzeniem słuchu, podejmując, jak wynika z badañ ${ }^{6}$, naukę w szkole ponadgimnazjalnej, posługuje

${ }^{3}$ A. Jaworska, A. Matczak, T. Szustrowa, Międzynarodowa Wykonaniowa Skala Leitera P-93. Polska standaryzacja: populacja ogólna 3-5 lat, dzieci głuche 3-14 lat, Pracowania Testów Psychologicznych, Warszawa 2009.

${ }^{4}$ J. Kobosko, Problemy zdrowia psychicznego dzieci głuchych i stabo styszacych oraz dzieci styszacych z populacji ogólnej w ocenie rodziców, „Nowa Audiofonologia” 2012, nr 1(1), s. 56-65.

${ }^{5}$ M. Dunaj, W stronę edukacji dwujęzycznej dzieci głuchych w Polsce, PZG, Łódź 2016.

${ }^{6}$ M. Januszewicz, M. Jura, J. Kowal, Każdy ma prawo do nauki. Prawo głuchych do dostępu do języka i edukacji, [w:] Edukacja głuchych, red. M. Sak, Biuro Rzecznika Praw Obywatelskich, Warszawa 2014. 
się polszczyzną jedynie na poziomie podstawowym. Tylko $9 \%$ badanych posiada kompetencje adekwatne do podjęcia nauki w szkole średniej. Powyższe wyniki jednoznacznie wskazują, iż testy gotowości szkolnej dzieci z wadą słuchu muszą uwzględniać ocenę kompetencji niewerbalnych oraz odnosić się do oceny językowej z uwzględnieniem polskiego języka migowego. Jak do tej pory trudności diagnostyczne dotyczą jednak braku narzędzi do oceny kompetencji językowej dzieci w języku migowym. Czym zatem obecnie dysponują poradnie? Co jest wykorzystywane przy ocenie gotowości szkolnej dzieci z wadą słuchu?

Narzędziem stosowanym, chociaż nie najbardziej rozpowszechnionym, jest Test Dojrzałości Szkolnej Dziecka z Wadą Stuchu autorstwa Urszuli Eckert, który do roku 2012 miał trzy wznowienia. W kolejnych wydaniach autorka modyfikowała zawarte w nim zadania tak, by w coraz bardziej kompleksowy sposób oceniać dojrzałość dziecka $\mathrm{z}$ uszkodzeniem słuchu. W wydaniu trzecim proponuje ocenę dziecka z wadą słuchu w zakresie:

- analizy i syntezy wzrokowej: klasyfikowania, porównywania, odwzorowywania i wnioskowania,

- arytmetyki,

- formy wypowiedzi, przy czym uwzględnia się: wypowiedz w języku migowym, migowo-słowną, jak również werbalną,

- orientacji przestrzennej,

- lateralizacji,

- uspołecznienia i samoobsługi.

Katarzyna Bieńkowska jest zdania7, że test ten, pomimo swego przeznaczenia, nie jest stosowany obligatoryjnie $\mathrm{w}$ poradniach psychologiczno-pedagogicznych. Diagnoza psychologiczno-pedagogiczna dzieci z wadą słuchu jest w nich dokonywana nierzadko w oparciu szereg innych narzędzi, w tym również testów przeznaczonych dla dzieci słyszących. Gdy wspomniana autorka prowadziła badania dotyczące oceny dojrzałości szkolnej dzieci z uszkodzeniem

${ }^{7}$ K. Bieńkowska, Gotowość szkolna dziecka z uszkodzonym narządem stuchu, Wydawnictwo Akademii Pedagogiki Specjalnej, Warszawa 2013. 
słuchu ${ }^{8}$, tylko $31 \%$ poradni w Polsce wykorzystywało w ramach procedury diagnostycznej wyżej wymieniony, specjalistyczny test.

Wprawdzie w ramach oceny gotowości szkolnej dziecka z wadą słuchu w sposób oczywisty należy zbadać wszystkie sfery rozwoju i predyspozycje do uczenia się, które ocenia się u dzieci słyszących, jednak specyfika badania musi uwzględniać przede wszystkim formułę skutecznego porozumiewania się niesłyszącym dzieckiem. Skorzystanie z narzędzi psychologiczno-pedagogicznych przeznaczonych dla dzieci słyszących wydaje się możliwe wówczas, gdy badane dziecko prezentuje wysoki poziom kompetencji komunikacyjnej i językowej w polskim języku fonicznym. W innej sytuacji należy rozważyć wybór testów bezsłownych, dostosowanych do możliwości percepcyjnych dziecka. Jest więc oczywiste, że osoba odpowiedzialna za ocenę dojrzałości szkolnej dziecka powinna mieć przygotowanie surdopedagogiczne. $W$ ramach tej procedury konieczna jest nie tylko ocena sprawności językowej dziecka z uszkodzeniem słuchu, ale i wyboru dalszej ścieżki kształcenia, umiejętności odczytywania przez nie mowy z ust. Sami rodzice dziecka z wadą słuchu zapytani o to, czy ich syn lub córka odczytują w ten sposób komunikaty, nie potrafią udzielić odpowiedzi na to pytanie 9 . Tymczasem Justyna Kowal dostrzegła, że blisko $80 \%$ dzieci z wadą słuchu w mniejszym lub większym stopniu czyta z ruchu warg10. Ocena tej kompetencji dziecka $z$ uszkodzeniem słuchu jest ważna, bo pozwala ustalić optymalny sposób porozumiewania się z otoczeniem oraz przekazywania treści w procesie kształcenia. Trzeba w tym miejscu podkreślić, że wskazania ze strony poradni co do wyboru ścieżki edukacyjnej są lepiej lub mniej uzasadniane. Wybór oczywiście w ostateczności zależy od rodziców. Jest on zawsze trudny, tym bardziej, że przepisy prawa w sposób niezwykle enig-

8 Ibidem.

9 Ibidem.

${ }^{10} \mathrm{~J}$. Kowal, Tożsamość kulturowa g/Głuchych a rzeczywistość w Polsce w aspekcie integracji, [w:] Młodzież głucha $i$ stabostyszaca w rodzinie $i$ otaczającym świecie, red. J. Kobosko, Wydawnictwo Stowarzyszenia „Usłyszeć Świat”, Warszawa 2009. 
matyczny przedstawiają warunki, jakie należałoby stworzyć w placówce, w której kształci się dziecko z wadą słuchu. Większość słyszących rodziców pragnie jednak, by ich dziecko uczęszczało do szkoły ogólnodostępnej11, przy czym część z nich preferuje klasy integracyjne jako miejsce przyjaźniejsze dziecku. Najważniejszym warunkiem optymalizacji kształcenia dziecka $\mathrm{z}$ wadą słuchu jest udział w tym procesie surdopedagoga. Jego rola nie sprowadza się bezpośrednio do procesu edukacji, ale odnosi się do opieki nad dzieckiem podczas przerw szkolnych i zajęć pozalekcyjnych. Istotna jest również jego wiodąca rola w organizacji całego procesu kształcenia dziecka.

Dla rodziców, do których należy decydujący głos w kwestii wyboru placówki szkolnej dziecka rozpoczynającego naukę, istotny jest system ofert, z którym winni zapoznać się na gruncie poradni. Doradztwo w tym zakresie pozostawia jednak wiele do życzenia. Urszula Bartnikowska wzmiankuje, iż słyszący rodzice są najczęściej zachęcani do odraczania dziecka lub umieszczania go w klasie integracyjnej ${ }^{12}$, co bez udziału surdopedagoga jako nauczyciela wspomagającego nie rozwiązuje problemów specjalnych potrzeb edukacyjnych dziecka. Jednocześnie rzadko w poradni psychologiczno-pedagogicznej, gdzie oceniana jest dojrzałość szkolna, rodzice mogą uzyskać informacje na temat walorów kształcenia specjalnego. Nie przedstawia się im pełnego wachlarza możliwości, w tym tej związanej z przeniesieniem dziecka ze szkoły specjalnej do ogólnodostępnej. Tymczasem wielu studentów niesłyszących i słabosłyszących okazuje się być absolwentami właśnie tego typu szkół.

Kolejne braki w zakresie dokonywania oceny gotowości szkolnej osób z wadą słuchu wynikają z faktu uwzględniania w tym procesie jedynie ewaluacji kompetencji dziecka przy jednoczesnym

${ }^{11}$ K. Bieńkowska, op. cit.

12 U. Bartnikowska, Sposób porozumiewania się a miejsce osoby z uszkodzonym stuchem w zarezerwowanej przestrzeni społecznej, [w:] Człowiek z niepełnosprawnościa w rezerwacie przestrzeni publicznej, red. Z. Gajdzica, Oficyna Wydawnicza "Impuls”, Kraków 2013. 
pominięciu wpływu środowiska na dziecięce możliwości w zakresie adaptacji szkolnej. Należy tu uwzględnić zarówno jakość wsparcia rozwoju dziecka ze strony rodziców, jak i placówki, do której może potencjalnie uczęszczać.

\section{Oferta edukacyjna dla dzieci z wadą słuchu}

Rodzice dzieci z wadą słuchu bardzo często utożsamiają wspomaganie rozwoju z procesem rehabilitacji słuchowej. Stojąc na straży postępów audytywno-werbalnych syna lub córki, zapominają o innych sferach rozwoju, ale co gorsza nierzadko stają się nieczuli na problemy emocjonalne dziecka, zgłaszane przez nie trudności. Są też rodzice, którzy odpowiedzialnymi za stymulowanie rozwoju dziecka czynią instytucje, tj. poradnie, placówki edukacyjne. Skutkuje to tym, że niespełna połowa z nich uczestniczy np. w zajęciach wyrównawczych lub terapeutycznych realizowanych na terenie poradni. Sytuację tę trzeba uwzględnić przy ocenie możliwości rozwojowych dziecka zawartej w opinii sporządzonej przez zespół diagnozujący. Drugim uwzględnianym przez zespół czynnikiem powinna być jakość wsparcia, jaką dziecko może uzyskać w warunkach danego systemu kształcenia. W sytuacji, gdy do czasu rozpoczęcia nauki szkolnej nie korzystało ono z instytucjonalnych form wychowania, np. przedszkolnej, to właśnie edukacja specjalna może być podstawowym prorozwojowym czynnikiem ułatwiającym dziecku adaptację szkolną.

Obecnie w Polsce działają 32 szkoły specjalizujące się w kształceniu uczniów z wadą słuchu ${ }^{13}$. Pracujące $\mathrm{w}$ ośrodkach tych osoby mają przygotowanie surdopedagogiczne i kształcą uczniów w oparciu o metody dostosowane do potrzeb osób niesłyszących i słabosłyszących, umożliwiając im rozwijanie dwóch języków, tj. języka

${ }^{13}$ M. Czajkowska-Kisil, A. Siepkowska, M. Sak, Edukacja głuchych w Polsce. Raport zespołu ds. g/Głuchych przy Rzeczniku Praw Obywatelskich, Biuro Rzecznika Praw Obywatelskich, Warszawa 2014. 
polskiego oraz polskiego języka migowego. W zależności od indywidualnych potrzeb i kompetencji uczniów, jeden z nich staje się dla dziecka prymarny. Na gruncie szkolnictwa specjalnego podejmowane są też próby kształcenia dwujęzycznego. Dla dzieci z wadą słuchu, dla których język migowy jest matczynym, kształcenie tego typu wydaje się być najoptymalniejszą ofertą edukacyjną. W tej formule kształcenia dziecko uczy się języka narodowego w oparciu o teksty pisane, mając świadomość odrębności języka narodowego i migowego. Jednocześnie sprawność w zakresie pierwszego z języków nabywa dzięki kompetencjom w posługiwaniu się tym drugim ${ }^{14}$.

Mimo przedstawionych powyżej walorów placówek specjalistycznych, trudno jest przekonać pracownikom poradni słyszących rodziców do tego, że nie są one przede wszystkim miejscem izolacji i stygmatyzacji. Dzieje się tak głównie wtedy, gdy posłanie dziecka do tego typu szkoły wymaga umieszczenia go w internacie. Udział rodziców w życiu szkolnym dziecka jest w tej sytuacji w sposób oczywisty ograniczony, co przesądza o barierach w zakresie zmiany rodzicielskich postaw $\mathrm{w}$ tym zakresie.

W okresie ostatnich dziesięciu lat rodzice dzieci z wadą słuchu coraz częściej podejmują decyzję o zapisaniu dziecka do szkoły ogólnodostępnej lub integracyjnej. Bez wątpienia główną zaletą tego typu kształcenia jest jego dostępność i fakt, że placówka edukacyjna to miejsce w lokalnym środowisku dziecka, ściśle z nim związane. Pracownicy poradni muszą jednak uwzględnić jakość wsparcia oferowanego dziecku w danym systemie kształcenia. Z tego względu, wskazując na możliwość kształcenia w warunkach inkluzji, muszą zdawać sobie sprawę, że wskazaniem jest tu z jednej strony duży potencjał intelektualny samego dziecka oraz zaangażowania rodziców w proces wspierania rozwoju córki lub syna, z drugiej powinni uwzględnić i przedstawić opiekunom plusy oraz minusy takiej formy kształcenia. Największym z nich może okazać

${ }_{14}$ M. Czajkowska-Kisil, Dwujęzyczne nauczanie głuchych w Polsce, „Szkoła Specjalna" 2006, nr 4, s. 265-275. 
się nie tylko brak jakiegokolwiek przygotowania nauczycieli z zakresu surdopedagogiki, ale ich przekonanie, że skoro dziecko uczy się w szkole ogólnodostępnej, to warunkiem realizacji procesu edukacji w takiej placówce jest jego dostosowanie się do wymogów tam panujących. W takiej sytuacji inkluzja nie będzie sprzyjać zarówno dostępowi do nauczanych treści, jak i języka15.

Jeżeli pracownicy poradni oceniają, że rodzice będą wspierać ucznia $\mathrm{z}$ wadą słuchu w procesie kształcenia i ma dla nich znaczenie kontakt córki lub syna zarówno ze środowiskiem osób słyszących, jak i niesłyszących, wtedy mogą zasugerować umieszczenie dziecka w klasie integracyjnej. Oczywiście dodatkową pomocą w tej sytuacji może okazać się wydane przez poradnię orzeczenie o specjalnych potrzebach edukacyjnych dziecka. Niezależnie jednak od wskazówek zawartych w takim orzeczeniu nie bez znaczenia dla adaptacji ucznia z wadą słuchu pozostaje również obecność w klasie innych dzieci niesłyszących lub słabosłyszących. Adaptacja $\mathrm{w}$ klasie integracyjnej, w gronie uczniów z tym samym typem niepełnosprawności jest łatwiejsza, bo przeżycia dziecka z wadą słuchu związane $z$ tym procesem znajdują zrozumienie $u$ osób jemu podobnych ${ }^{16}$. W sytuacji, gdy klasa integracyjna nie jest jednak sprofilowana typem niepełnosprawności słuchowej, z czym obecnie w polskich warunkach spotykamy się najczęściej, uczeń z wadą słuchu nierzadko postrzegany jest lub traktowany jako osoba o ograniczonym potencjale intelektualnym i sam wówczas nie wie, z jaką grupą dzieci powinien się identyfikować - czy z uczniami słyszącymi, czy też np. dziećmi z niepełnosprawnością intelektualną ${ }^{17}$. Powyżej opisana sytuacja ma także swój wymiar edukacyjny, albowiem gdy w klasie integracyjnej, nauczycielem wspomagającym jest oligofrenopedagog, specjalne potrzeby edukacyjne dziecka z wadą słuchu mogą być zaspokojone w stopniu, na który pozwala

${ }^{15}$ M. Januszewicz, M. Jura, J. Kowal, op. cit.

${ }_{16}$ M. Sak, Kształcenie głuchych w szkołach masowych $i$ w klasach mieszanych z innymi niepetnosprawnościami, [w:] Edukacja głuchych, red. M. Sak Biuro Rzecznika Spraw Obywatelskich, Warszawa 2014.

${ }_{17}$ M. Czajkowska-Kisil, A. Siepkowska, M. Sak, op. cit. 
jego merytoryczne przygotowanie. Ten aspekt kształcenia integracyjnego powinien z pewnością zostać uwzględniony przy wskazaniach ze strony poradni, co do specyfiki potrzeb dziecka z wadą słuchu.

\section{Podsumowanie}

Z podjętych przeze mnie $\mathrm{w}$ niniejszym tekście rozważań wyni$\mathrm{ka}$, że ocena gotowości szkolnej dziecka $\mathrm{z}$ wadą słuchu $\mathrm{w}$ ramach diagnozy psychologiczno-pedagogicznej nie jest zadaniem łatwym. Potwierdzają ten fakt m.in. badania dojrzałości szkolnej dzieci z uszkodzonym słuchem zrealizowane przez K. Bieńkowską18. Wynika z nich, że diagnozy takiej nie powinny realizować osoby, które nie posiadają formalnego wykształcenia z zakresu surdopedagogiki, przy czym wymóg ten dotyczy zarówno pedagoga, jak i psychologa. W przeciwnym razie istnieje ryzyko prowadzenia diagnozy przez osobę nie w pełni kompetentną, co może rzutować na nieadekwatny sposób oceny funkcjonowania dziecka.

W samej diagnozie z pewnością warto uwzględnić poziom jakości wsparcia oferowanego dziecku $z$ wadą słuchu ze strony środowiska stymulującego rozwój. Kluczowa rola przypada tu oczywiście rodzicom, ale nie bez znaczenia pozostaje fakt objęcia dziecka $\mathrm{z}$ wadą słuchu edukacją przedszkolną. Bez wątpienia to, że dziecko z wadą słuchu w czasie adekwatnym do wieku rozwojowego osiąga dojrzałość szkolną, koreluje z faktem objęcia go wczesną interwencją, tj. szybką diagnozą audiologiczną, oprotezowaniem słuchu i rehabilitacją oraz edukacją przedszkolną. Nie ma przy tym znaczenia, czy wymienione działania realizowane były na terenie placówki specjalnej, czy ogólnodostępnej z oddziałami integracyjnymi.

Kolejną istotną kwestią jest uświadomienie opiekunom dziecka z wadą słuchu, że wybór szkoły specjalnej to nie mniejsze zło, ale w wielu przypadkach większe dobro. To właśnie kadra ośrodków szkolno-wychowawczych posiada obligatoryjne kwalifikacje z za-

${ }^{18}$ K. Bieńkowska, op. cit. 
kresu surdopedagogiki, znajomość języka migowego, a w procesie edukacji stara się o indywidualizację procesu nauczania i wychowania. Zgoła odmiennie wygląda sytuacja adaptacyjnej ścieżki dziecka z wadą słuchu w szkole ogólnodostępnej ${ }^{19}$.

Tutaj nauczyciele oczekują, że to uczeń z uszkodzeniem słuchu będzie miał dobrze opanowany polski język foniczny i do tego kompetencje $\mathrm{w}$ zakresie odczytywania mowy $\mathrm{z}$ ust na wysokim poziomie, co w konsekwencji umożliwi mu dostosowanie się do wymagań stawianych uczniom słyszącym. Rozważna diagnoza gotowości szkolnej dziecka z wadą słuchu powinna bez wątpienia uwzględniać specyfikę inkluzji w polskich warunkach. Trudności edukacyjne, a w dalszej kolejności niepowodzenia dziecka z uszkodzeniem słuchu w klasie ogólnodostępnej, skutkujące zmianą placówki na specjalną, w pewnej mierze stawiają pod znakiem zapytania opinię z poradni psychologiczno-pedagogicznej, która powinna uwzględniać mocne i słabe strony ucznia oraz systemu, w jakim przyjdzie mu się kształcić.

Zaskakujący jest z pewnością fakt, że w niektórych przypadkach nauczyciele edukacji elementarnej opiekujący się dziećmi z wadą słuchu nigdy nie widzieli diagnozy psychologiczno-pedagogicznej swoich uczniów. W tej sytuacji pozostaje im dokonywać ewaluacji dziecka samodzielnie, co jednak nie gwarantuje kompleksowego charakteru diagnozy.

Przytoczone powyżej problemy stanowią oczywiście tylko część spośród tych związanych z oceną gotowości szkolnej dzieci z uszkodzeniem słuchu. Kontrowersje wokół diagnozy psychologiczno-pedagogicznej wyżej wymienionej grupy dzieci, o których piszę w niniejszym opracowaniu, stanowią bez wątpienia podstawę dla dokonywania zmian w tym obszarze.

\section{Bibliografia}

Bartnikowska U., Sposób porozumiewania się a miejsce osoby z uszkodzonym stuchem w zarezerwowanej przestrzeni społecznej, [w:] Człowiek z niepetnosprawnościa w re-

19 U. Bartnikowska, op. cit. 
zerwacie przestrzeni publicznej, red. Z. Gajdzica, Oficyna Wydawnicza „Impuls”, Kraków 2013.

Bieńkowska K., Gotowość szkolna dziecka z uszkodzonym narządem stuchu, Wydawnictwo Akademii Pedagogiki Specjalnej, Warszawa 2013.

Brzezińska A., Matejczuk J., Nowotnik A., Wspomaganie rozwoju dzieci 5-7 letnich a ich gotowość do radzenia sobie z wyzwaniami szkoty, „Edukacja” 2012, 1(117).

Czajkowska-Kisil M., Dwujezzyczne nauczanie głuchych w Polsce, "Szkoła Specjalna” 2006, nr 4.

Czajkowska-Kisil M., Siepkowska A., Sak M., Edukacja głuchych w Polsce. Raport zespołu ds. g/Gluchych przy Rzeczniku Praw Obywatelskich, Biuro Rzecznika Praw Obywatelskich, Warszawa 2014.

Dunaj M., W stronę edukacji dwujezycznej dzieci gluchych w Polsce, PZG, Łódź 2016.

Januszewicz M., Jura M., Kowal J., Każdy ma prawo do nauki. Prawo głuchych do dostępu do jezyka i edukacji, [w:] Edukacja głuchych, red. M. Sak, Biuro Rzecznika Praw Obywatelskich, Warszawa 2014.

Jaworska A., Matczak A., Szustrowa T., Międzynarodowa Wykonaniowa Skala Leitera P-93. Polska standaryzacja: populacja ogólna 3-5 lat, dzieci głuche 3-14 lat, Pracowania Testów Psychologicznych, Warszawa 2009.

Kobosko J., Problemy zdrowia psychicznego dzieci głuchych $i$ stabo styszacych oraz dzieci styszacych z populacji ogólnej w ocenie rodziców, "Nowa Audiofonologia" 2012, nr 1(1).

Kowal J., Tożsamość kulturowa g/Głuchych a rzeczywistość w Polsce w aspekcie integracji, [w:] Młodzież głucha i stabostysząca w rodzinie i otaczającym świecie, red. J. Kobosko, Wydawnictwa Stowarzyszenia „Usłyszeć Świat”, Warszawa 2009.

Sak M., Ksztatcenie głuchych w szkotach masowych i w klasach mieszanych $z$ innymi niepetnosprawnościami, [w:] Edukacja głuchych, red. M. Sak, Biuro Rzecznika Spraw Obywatelskich, Warszawa 2014. 